\title{
ESTUDO DA VARIABILIDADE GENÉTICA DAS POPULAÇÕES DE MILHO CAPIXABAS POR MEIO DE MARCADORES MOLECULARES
}

\author{
Larícia Olária Emerick Silva ${ }^{1}$ \\ Fernanda Vargas Valadares ${ }^{2}$ \\ Rafael Nunes de Almeida ${ }^{3}$ \\ José Dias de Souza Neto ${ }^{4}$ \\ Ana Paula Cândido Gabriel Berilli ${ }^{5}$ \\ Monique Moreira Moulin 6
}

Resumo: O objetivo do trabalho foi avaliar a variabilidade genética, via ISSR (Inter sequência simples repetida), de 13 populações de polinização aberta de milho do banco de germoplasma do Ifes, Campus de Alegre. Para análise molecular via ISSR foram adotados os procedimentos de acordo com as metodologias já estabelecidas para milho com algumas modificações, sendo testados três protocolos de extração. Foi selecionado apenas um dos protocolos de extração por apresentar maior nitidez das bandas de DNA. Procedeu-se a triagem dos iniciadores, sendo que os iniciadores UBC 890, (AC)8YA, (GA)8CTT, UBC 812, UBC 835 foram os que apresentaram os melhores perfis eletroforéticos e maior polimorfismo, sendo possível constatar uma variabilidade genotípica considerável para os acessos de milho coletados no estado do Espírito Santo.

Palavras-chave: Análise molecular; Milho; Polimorfismo.

\footnotetext{
${ }^{1}$ Graduanda em Licenciatura em Ciências Biológicas do Instituto Federal do Espírito Santo Campus de Alegre, Brasil. Email: lariciaemericklara@hotmail.com.

2 Graduanda em Bacharelado em Ciências Biológicas do Instituto Federal do Espírito Santo Campus de Alegre, Brasil. Email: fernanda_valladares@hotmail.com.

3 Mestrando em Agroecologia do Instituto Federal do Espírito Santo Campus de Alegre, Brasil. Email: rafaelcabral1500@gmail.com.

${ }^{4}$ Técnico MSc. do Laboratório de Genética e Biologia Molecular do Instituto Federal do Espírito Santo Campus de Alegre, Brasil. Email: jdiassneto@gmail.com.

5 Professora PhD do Instituto Federal do Espírito Santo Campus Itapina em Colatina, Brasil. Email: anapaula.apgo@gmail.com.

6 5Professora Doutora do Instituto Federal do Espírito Santo Campus de Alegre, Brasil. Email: moniquemoulin@gmail.com.
} 